\title{
Kinship, Law, and Narrative
}

The first question that Moses rhetorically poses to the tribes in the NTT expresses a principle of national belonging that lies at the heart of our investigation: "Shall your brothers go to war while you reside here?" (Num. 32:6, emphasis added). ${ }^{\mathrm{I}}$ Later, Joshua reminds the Transjordanian tribes of their promise to accompany their brothers/kin until they have successfully taken possession of their land (Josh. I:I 2-I 5). In the end, he discharges the warriors after commending them for their faithful service on the battlefield: "You have not forsaken your brothers these many days, indeed to this very day, but have faithfully kept the charge of Yhwh your god. Now Yhwh your god has given rest to your brothers, as he promised them. You may therefore return to your tents in the land of your holding ... ." (Josh. 22:I-6, emphasis added). After returning to their homes in the Transjordan, the eastern tribes eventually forget about their kin in the west and, by the time of Deborah, are no longer willing to contribute to the nation's war efforts. ${ }^{2}$

I The line is often cited now by Israeli media in relation to the ultra-Orthodox who do not serve in the Israeli Defense Forces (IDF) yet expect not only full citizenship rights but a disproportionate share of social welfare.

2 In the Song of Deborah and Numbers 32 , the verb "reside" $(y-\check{s}-b)$ appears in an indictment of the Transjordanian tribes for dodging their duties to the nation. Read on their own, both Moses's and Deborah's queries presuppose and affirm the belonging of the Transjordanian communities they censure. Yet when these texts are read sequentially as part of the wider narrative of Genesis-Kings, the reader should understand that these eastern tribes had originally made a significant contribution to the conquest of Canaan, but after returning to their homes in the Transjordan, they eventually forget about their kin in the west and, by the time of Deborah, are no longer are willing to contribute to the nation's war efforts. 
Our investigation in the preceding chapters has demonstrated how later generations of scribes reworked the NTT, expanding this fraternal rationale for the tribes' wartime service. Originally, what motivates the eastern tribes' participation in the conquest of Canaan is a sense of kinship; the members of the nation are "brothers in arms." Yet, thanks to the contributions of later scribes who left their imprint on the NTT, what motivates the tribes is now not only the unspoken, instinctual expectations of kinship/brotherhood but also, and more fundamentally, an allegiance to the explicit commandment of Yhwh spoken through Moses.

In modern times, the codification of law and the use of it to undermine hierarchical-aristocratic structures have been crucial to the emergence of national communities. In the context of Israel's and Judah's wars with imperial powers, a body of written law had a central role to play: When the state was still intact and mobilizing for battle, it could promote solidarity by regulating power and privileges among rival groups and institutions. But when the nation was defeated and dispersed, and a native king and army were no longer there to defend its territorial borders, the law could demarcate communal boundaries and provide a unifying political vision.

In this final chapter of Part Two, we begin by exploring, with the help of comparative texts, the conceptual bond between kinship and military service. Given the limitations of ethnicity as the basis of national identity, our investigation will take us to a political theory that emerged in postI945 Germany, which offers an alternative to an ethnic or cultural framework for national belonging. Thereafter, we examine how a national narrative can inculcate a sense of kinship and affection for the law, and consider what makes a text truly sacred.

\section{FROM STATE DIPLOMACY TO NATIONAL BELONGING}

The themes of fraternity and wartime service, which we discovered in the substratum of the NTT, run hand in glove throughout a long history of social-political discourse extending from antiquity to contemporary times. ${ }^{3}$ A paradigmatic case is found in I Maccabees, which cites a letter

3 A recent example is the 2007 IDF Code of Ethics, which lays down rules resembling the US military ideals of mutual responsibility and never leaving a wounded comrade in the field: "The IDF servicemen and women will act out of fraternity and devotion to their comrades, and will always go to their assistance when they need their help or depend on them, despite any danger or difficulty, even to the point of risking their lives." 
that Jonathan (the Judean high priest and military commander who succeeded his father Judas) sends to the Spartans requesting their military assistance. Rather than formulating his request directly, Jonathan claims to be interested merely in renewing, after many years, the old "friendship and alliance" (philia kai symmachia) and "family ties/fraternity" (adelphotetos) between the Judeans and their brothers, the Spartans. He refers to an earlier letter, from the end of the fourth century BCE, sent by the Spartan king Arius to Jerusalem, apparently also petitioning for military assistance:

Already in times past the high priest Onias received a letter from Arius, who was king among you. As the appended copy shows, it stated that you are our brothers. Onias welcomed the envoy with honor, and received the letter, which contained a clear declaration of alliance and friendship. Though we have no need of these things - for the holy books in our hands are our source of strength - we are seeking to renew our family ties and friendship with you, so that we may not become estranged from you. Considerable time has passed since you sent your letter to us, yet we remember you constantly on every occasion, both at our festivals and on other appropriate days, at the sacrifices that we offer, and in our prayers, as it is right and proper to remember brothers. I Macc. I 2:7-I I (NRSV)

In response, the Spartans send a letter in which they claim to have researched and discovered in the written record that indeed "the Spartans and the Judeans are brothers (adelphoi) and of the family of Abraham (ek genous Abraam)." " The correspondence differs from earlier agreements with Rome in which "the assembly" (plèthos) of the Jews becomes "friends and allies" (symmachoi kai philoi) of the Romans, without saying anything about brotherhood (see I Macc. 8:I7-32). ${ }^{5}$

Though most likely fictive, the Spartan correspondence superbly illustrates a typical scenario of statecraft: I) one party faces a military threat and needs the assistance of another; 2) the political exigencies lead to an alliance; 3) and the alliance directly fosters fraternity between the two parties as they construct - with the help of careful research - a narrative of their shared past and heritage.

${ }^{4}$ See the classic discussion in Michael S. Ginsburg, "Sparta and Judaea," Classical Philology, 23 (I934), II7-I22. Subsequent scholarship has raised serious questions about the authenticity of the correspondence, which situates Jonathan at the center of geopolitics.

5 On the form of this agreement, see D. A. Bowman, "The Formula Sociorum in the Second and First Centuries BC," Classical Journal, 85 (I989-90), 330-336; L. T. Zollschan, "Politics and the Orality of Roman Peace-Making" in Craig Cooper (ed.), The Politics of Orality (Leiden: Brill, 2007), I7 I-I90. 
In his commentary on these letters, Jonathan Goldstein compares the statement that the Spartans share property with the Judeans - and hence are implicitly willing to contribute their resources to the Judean war effort - to two biblical texts referring to shared resources and fraternity. ${ }^{6}$ In I Kings 22, a king of Israel urges Jehoshaphat, king of Judah, to go to war with him against the Arameans in order to take back Ramoth-Gilead, a strategic site in the Transjordan. In response, Jehoshaphat affirms, "I am as you are. My people are as your people. My horses are your horses" (v. 4). Similarly, in 2 Kings 3, King Jehoram mobilizes his troops to reassert Israelite hegemony over the Transjordanian kingdom of Moab. He sends Jehoshaphat a letter, asking him to join him on his campaign, to which the Judean king responds once again: "I will go: I am as you are. My people are as your people. My horses are as your horses" (v. 7). These declarations play on the double meaning of "people," which in Hebrew, as in many other languages, can bear the meaning of not only population or subjects but also troops or nation in arms.

Other texts use the language of unity. For example, the Hittite ruler Muršili II (I343-I 295 BCE) writes to Talmišarruma of Aleppo, "May all of us together and our house be one [gabbani u bïtni lü ištēn]!" Most often, such declarations of oneness are found in the context of preparations for a joint military operation. ${ }^{7}$ Terms of fraternity and oneness belong to the vernacular of ancient international diplomacy. One of the most consistent features of the Akkadian treaty tradition is the expectation that partners will participate in each other's war efforts and come to each other's defense. The treaties and official correspondence are suffused with the rhetoric of "brotherhood" (ahhūtu) and "close friendship" $(r \bar{a} ' \bar{\imath} m \bar{u} t u){ }^{8}$ Thus, when the Hittite king Hattušili III (I267-I237 BCE) writes to his Kassite ally Kadašman-Enlil II of Babylon, he refers, as does Jonathan in I

${ }^{6}$ Jonathan A. Goldstein, I Maccabees (New York: Doubleday, I976).

7 See Mark Smith, “'Your People Shall Be My People': Family and Covenant in Ruth I:I6-I7," Catholic Biblical Quarterly, 69 (2007), 242-258. The texts quoted in this section are all taken from Paul Kalluveettil, Declaration and Covenant: A Comprehensive Review of Covenant Formulae from the Old Testament and the Ancient Near East (Rome: Pontifical Biblical Institute, I982), 99-I03.

${ }^{8}$ The letters are collected and translated in the first half of William L. Moran, The Amarna Letters (Baltimore: Hopkins, I992). See also B. Lafont, "Relations internationales, alliances et diplomatie au temps des royaumes amorrites: Essai de synthèse" in Jean-Marie Durand and Dominique Charpin (eds.), Mari, Ébla et les Hourrites: Dix ans de travaux; Actes du colloque international (Paris, mai I993): Deuxième partie (Paris: ERC, 200I), $2 \mathrm{I} 3-328$. 
Maccabees, to a past history of friendship and fraternity: "When your father and I established close friendship and became brothers, we spoke thus: 'We are brothers: We should be the enemy of one who is an enemy to anyone of us, a friend to the one who is a friend of anyone of us." One should not dismiss this talk of brotherhood as mere rhetoric. A letter from Šaušgamuwa, the king of Amurru, to Ammittamru II, king of Ugarit (I 260-I 235 BCE), asserts, "My brother, see, we, you and I, are brothers, sons of one and the same man; brothers we are!" Šaušgamuwa would have likely protested any etic distinction between "constructed" kinship and "real" consanguinity.

Fraternity between two separate polities/peoples brings with it obligations and a moral imperative, just as it does within a political community. The obligations differ only in degree, not in quality. In both cases, they are understood to derive from a kinship that long precedes the moment in which a contribution or action is called for. This explains why treaties are understood to reaffirm bonds that are already long-standing. Moreover, the ratification of international treaties in the ancient world was often accompanied by blood rites, commensality, and intermarriage, which otherwise characterize familial/national bonds. ${ }^{9}$

Throughout the biblical corpus, we can study how scribes applied standard diplomatic parlance of states to their project of creating a form of peoplehood that is capable of withstanding the loss of statehood. The actors are no longer kings and diplomats but rather groups and communities within a political community. In forging this new concept of peoplehood, the biblical scribes drew heavily on official diplomatic language between kings. Thus, the story of Ruth uses language that is much the same as King Jehoshaphat's formal declarations cited above. Establishing a point of departure for the narrative, Ruth proclaims to her mother-inlaw:

For where you go, I will go. Where you stay, I will stay. Your people shall be my people, and your god my god. Where you die, I will die, and there I will be buried. Ruth I:I6-I $7^{\text {I0 }}$

Using the rhetoric of vassalage, the Moabite protagonist makes a pledge to join the people of her mother-in-law. As in the book of Genesis, the story of Ruth directs attention away from rulers and

9 The far-reaching ramifications of treaties for kinship relations and political-ethnic boundaries explain the anxiety of many biblical authors with respect to alliances between Israel and other peoples.

Iо For the overlap between Ruth's and Jehoshaphat's pledges, see Smith, "Your People." 
diplomacy to humble, quotidian matters in the private lives of families and widows. It portrays how personal relationships built on hesed (generosity, hospitality, or loving kindness) redound to the strength of the entire nation. ${ }^{\mathrm{II}}$

The biblical writers developed the principles of kinship and national belonging in sundry and impressive ways. Thus, what the authors of Genesis achieve through narrative (creating a family from what were originally unrelated clans), the authors of the Holiness and Deuteronomic codes express through divine command: "Thou shalt love thy neighbor as thyself - I am Yhwh!” (Lev. I9:I8).

In the book of Joshua, Israel is a united people in arms, with a common history that precedes military action. Canaan, on the other hand, is inhabited by numerous city-states ruled by monarchs; with their professional armies, they form coalitions with other kings solely for the purpose of fighting Israel. This polarity - Canaanite states versus the Israelite nation - must be borne in mind when interpreting the NTT as a whole, which repeatedly presents the eastern tribes affirming their primordial fraternity with the people of Israel as they prepare for war against the kings of Canaan. ${ }^{\mathrm{I}}$

\section{CONSTITUTIONAL PATRIOTISM}

The authors of the NTT addressed long-standing issues of belonging posed by the Transjordanian communities by commemorating their service on the front lines, and in so doing, they synthesized narrative, kinship, and law - the three defining features of the national identity articulated throughout the biblical corpus. The story told by these scribes (narrative) depicts Transjordanians fighting for their Cisjordanian brethren (kinship) in keeping with the Mosaic commandment (law). In the framework of their impressive narrative, fidelity to the law doesn't supplant fraternal solidarity; it supplements it.

${ }^{\text {II }}$ This point is developed at length by Tamara Cohn Eskenazi in her commentary (coauthored with Tikva Frymer-Kensky), Ruth: The JPS Bible Commentary (Philadelphia: Jewish Publication Society, 20II).

I2 At the other end of the biblical narrative, and drawing on themes from the book of Joshua, Nehemiah tells how Judah's neighbors form a military alliance for the purpose of assailing Jerusalem and interrupting the construction of the wall. In preparation for the onslaught, Nehemiah assembles a militia force from Jerusalem's inhabitants and exhorts it to "fight for your brothers, sons, daughters, wives, and homes" (4:8; cf. I Macc. 5:32 and passim). 
The tension in the NTT between fraternity/kinship, on the one hand, and fidelity to (divine) law, on the other, brings to mind the notion of constitutional patriotism (Verfassungspatriotismus), which the political scientist Dolf Sternberger and the philosopher Jürgen Habermas formulated in the aftermath of the terror perpetrated by the Third Reich. According to this postnationalistic conception of citizenship, what must unite citizens of a state is their allegiance to a collectively ratified constitution, not culture, language, descent, kinship, or ethnicity. It's the constitution, not a primordial ethnic community, that is the object of identification, affections, and obligations.

Even though Sternberger formulated the concept in I979, in honor of the thirtieth anniversary of the new West German constitution, the underlying notion can be found at work already in other times and places. As Sternberger himself pointed out, both Switzerland and the United States are ethnically diverse states (the former with four official languages) that celebrate, in annual civic rituals, the signing of formal declarations. (In the United States, it's the Declaration of Independence of 1776 , and in Switzerland the Bundesbrief of I29I.) Habermas traces the origins of this concept beyond the social contract theories of Hobbes and Rousseau back to Aristotle's republican thought, without acknowledging that the concept is treated extensively in the Hebrew Bible. ${ }^{\mathrm{I} 3}$

Constitutional patriotism, however, has serious limitations as an alternative to a historical or cultural basis of identification. Josef Joffe, publisher-editor of Die Zeit, observes that a legal document can hardly "deliver a reason for attachment to a particular country, let alone obligation to that state." Although Sternberger points to the example of the United States, American identity has commonly appealed to a collective experience in the past - liberation from monarchic oppression - to foster a sense of solidarity and mutual obligations (on this point, see the discussion of Whitaker's war sermon in Part III). "Constitutional patriotism is the interchangeable loyalty to rules that can be demanded by every liberal constitutional state. Affection, however, is the answer to the question: Why am I living under this law and not another?" ${ }^{44}$

${ }^{13}$ On the origins of this concept, see Jan-Werner Müller, Constitutional Patriotism (Princeton: Princeton University Press, 2007).

${ }^{14}$ Josef Joffe, "Deutsch und Stolz," Die Zeit, March 22, 200I. For other critiques, see Bernard Yack, "The Myth of the Civic Nation," Critical Review, Io (I996), I93-2 I I; Thomas Mertens, "Cosmopolitan and Citizenship: Kant Against Habermas," European Journal of Philosophy, 3 (I996), 328-347; David Miller, On Nationality (Oxford: Oxford University Press, I995). 
Joffe's observations with respect to history are perceptive. The law means little if it is not embedded in a shared past that the members of the community create through a collaborative effort of political imagination. Law requires a story; nomos needs narrative. Hence the title of Rogers Smith's superb study Stories of Peoplehood. ${ }^{\mathrm{I}}$ A people needs a past, and especially stories about that past. Without narration, there is no nation.

\section{HOW DOES A TEXT BECOME SACRED?}

While the biblical scribes developed, with staggering sophistication, the notion of fidelity to a body of written law, they appear to have realized what the citizens of many countries today are still learning - namely, that when a constitution is not accompanied by a sense of kinship, it's empty and ineffective, and that the best way to foster a sense of kinship is through a narrative that preserves and honors the diverse stories of its members.

If it's difficult for a modern democratic constitution to inspire its citizens' affection and devotion, as Joffe pointed out, how much more so for a declaration of the singular deeds of a dead monarch or defunct dynasty? Consider the epilogue to the famous Code of Hammurabi:

Hammurabi, the king of righteousness, on whom Shamash has conferred right (or law) am I. My words are well considered; my deeds are not equaled; to bring low those that were high; to humble the proud, to expel insolence. If a succeeding ruler considers my words, which I have written in this my inscription, if he do not annul my law, nor corrupt my words, nor change my monument, then may Shamash lengthen that king's reign $\ldots .{ }^{16}$

Although Hammurabi's laws are majestic in their formulation, and although they champion ideals of social justice, they were completely forgotten until modern historians rediscovered them among the ruins of ancient societies. Why so? They fell into oblivion because, like so many other monarchic display inscriptions from the ancient Near East, they are all about the king and his unparalleled achievements and status. The laws are embedded in a narrative, but that narrative is all about royal power. It's not the story of a larger people, as we find in the Bible. The audience it

${ }^{15}$ Rogers Smith, Stories of Peoplehood: The Politics and Morals of Political Membership (New York: Cambridge University Press, 2003).

${ }^{16}$ The Code of Hammurabi, King of Babylon, trans. R. F. Harper (Chicago: University of Chicago Press, I904), 43. 
addresses is the community of (present and future) kings, not a national community.

Steven Grosby notes that this monarchic text, like so many others of its kind, "exists today as an objective symbolic configuration ... . It is not 'animated' by being constantly 'reactivated' in the minds of a number of individuals ... . It is not 'alive' by being part of the shared 'mental environment' of each of many individuals." ${ }^{17}$ Even though Hammurabi's laws were exceptional in the ancient world for their wide reception and their potential for "activation," Grosby's observations about this text's inability to awaken and strengthen a corporate consciousness are to the point. Without being anchored in a people's common story, the laws failed to create, let alone sustain, a reading public that claimed fidelity to them and placed them at the center of its collective life.

But what about the countless cuneiform and hieroglyphic texts from the ancient Near East that claim to contain the very words of the gods or that were once deemed to be sacred themselves? Our knowledge of these texts today is due solely to the valiant efforts of archeologists to excavate them from layers of destruction and of philologists to decipher the dead languages in which they are written. Why is that so?

Reviewing a scholarly publication in the Wall Street Journal, Sarah Ruden notes that what really matters is not a text's claim to be holy but the its ability to convince a reading community that it is indeed holy:

No words were more self-consciously and thunderously "holy" than the curses inscribed on pharaohs' tombs as warnings, but these must merely have entertained the robbers who sacked every funerary hoard they could find. What's at issue isn't a writer's intention that a text be holy, or any authority's treatment of it as holy, but the broad assent that the text can win for its holiness. ${ }^{\text {I } 8}$

If a text manages to win a community's broad assent to its own claim to be holy, to contain the very "Word of God," and if the members of that community make the text the center of their familial and collective lives even in the absence of a king or state authority that ensures such broad and robust assent, then there must be something in those holy words that the members of the community deem relevant to their own concerns. And indeed the kinds of stories, laws, proverbs, prophecies, psalms, laments,

${ }^{17}$ Steven Grosby, Biblical Ideas of Nationality: Ancient and Modern (Winona Lake: Eisenbrauns, 2002), I Iо.

I8 Sarah Ruden, review of How the Bible Became Holy, by Michael L. Satlow, Wall Street Journal, July I I, 20I4. 
and love poetry that we find in the biblical corpus bear directly on diverse matters of both communal and individual life.

One would be hard pressed to find a more dramatic illustration of "the broad assent that the text can win for its holiness" than the account in Nehemiah 8-IO. After defeat and destruction, the inhabitants of Judah ("all the people") come together and express their longing for "the book of the law of Moses." Later, the nation's story is recounted in one of the longest prayers in the Bible, and, in response to the past portrayed in that prayer, all members of the community "join their kin" in a covenant to follow Yhwh's commandments. In these scenes, there is no king who looms above the crowd - only a scribe who has devoted himself to studying Yhwh's law and teaching it to the nation (see Ezra 7:I0). ${ }^{\text {I9 }}$

\section{A NORMATIVE PAST}

Another question that has to be considered is authority. Hammurabi's laws are not legally binding or absolute; rather, they are one piece of a larger royal performance of power. By contrast, biblical law and its supporting narrative are about the activation of a national community. What must ultimately prevail, according to the dominant political theology articulated in our biblical texts, is the divine will as expressed in laws revealed to the nation (not the king) after it had been liberated from tyranny. Without memories of that liberation, generated and sustained by the collective imagination, the law loses it plausibility and authority. Owing to this intuition, biblical law is transmitted and interpreted in the framework of a narrative of national liberation, in contrast to the legal corpora collected and displayed by Mesopotamian kings.

Stretching from the creation of the world in Genesis to the destruction of Jerusalem in Kings, the biblical narrative establishes the veracity of the Torah's claims about itself - that the nation will suffer defeat and the loss of its homeland if it fails to abide by the Torah's instructions and implement its vision of a flourishing society. However, the narrative's raison d'être cannot be reduced to an attempt to construct a "normative past."

19 On the ways in which Neh. 9 functions as a historical prologue to the pact in Neh. IO (resembling the form of Hittite treaties), see Wright, Rebuilding Identity, 2 I 2-220.

20 The discussion in this chapter is presented at greater length, and with special attention to the conditional and volitional character of the covenant, in Jacob L. Wright, "The Raison d'Être of the Biblical Covenant: Assessing Mendenhall's Emphasis on Kinship," MAARAV, 24 (forthcoming). On the concept of normative past, see Jan Assmann, Religion and Cultural Memory (Stanford: Stanford University Press, 2006). While the 
Its purpose is more ambitious - namely, to foster a sense of kinship and solidarity among the nation's members and to inspire affection for, and loyalty to, a god who liberated and blessed them with a homeland.

Beginning with the stories of two kingdoms that were once one, scribes, working across a span of centuries, created a narrative that now begins with the story of a family that evolved into a nation. That narrative existed and evolved for generations before it came to serve as a framework for Yhwh's instructions to the nation in the form of divine laws. Even if these laws are not coeval with the surrounding narrative, Yhwh is central to the latter, which, in its final forms, tells the story of a long and intimate relationship between him and his people. Antecedents to this narrative may have been nontheological, but the formation of the narrative, evolving from the combination and synthesis of older works, presupposes Yhwh's perspective.

As the covenant between Yhwh and Israel becomes ever more central to this narrative, the deity develops a more robust personality. This personality is on display from the very first chapters of Genesis, which portray Yhwh struggling with his creation in a series of trials and errors. $\mathrm{He}$ eventually decides to take a new route, working through an aged couple to bring a people into existence. History becomes the story of the relationship between this nation and its deity, and that relationship is conceived of as a love affair: Yhwh is the husband, Israel his wife, and the covenant their marriage contract. Hosea presents the restoration of this relationship after a divorce. The couple reunites, and this reunion is accompanied by a change in Yhwh's heart: he declares his intention to take her to a place of solitude and pursue her with tenderness. "Therefore, I will now allure her, and bring her into the wilderness, and speak tenderly to her .... There she shall respond as in the days of her youth, as at the time when she came out of the land of Egypt" (Hos. 2:I4-I 5).

Here and throughout the prophets, a future is imagined in which the nation and Yhwh return to the early, innocent, happy days of their life together. Those days exist only in the minds of a community

question of authority is certainly central to the origins and evolution of the larger biblical narratives, and while Assmann's concept of normative past nicely captures the problems facing a community that no longer has a king/state of its own, the imagination of ideal pasts by biblical scribes (whether it be the time of the exodus and conquest or the days of the United Monarchy) grows out of an intuition that informs narrative constructions from both defeated peoples and powerful rulers: persuading a public to reinstitute something that (allegedly) once worked is easier than persuading it to try something completely new. 
that imagines them, and inasmuch as the past is mythic, then the return to it is nothing less than the beginning. ${ }^{2 I}$

${ }^{21}$ Although the biblical project is a thoroughly political-theological one, we must not lose sight of the fact that other writings that are consciously and thoroughly nontheological have made their way into the biblical corpus. The most obvious example is the book of Esther, which has nothing whatsoever to say about a divine presence. It portrays the Jewish people as a far-flung nation, inhabiting a massive international empire, yet still

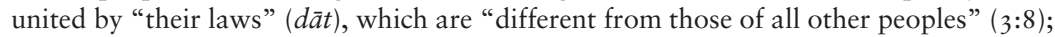
the role of the deity has been assumed fully by law. Efforts to domesticate the book by theologizing its message (e.g., Jonathan Grossman, Esther: The Outer Narrative and the Hidden Meaning [Winona Lake: Eisenbrauns, 20I I]) have a long history. Alternative editions of the works, transmitted in Greek, feature repeated and lengthy prayers along with descriptions of other acts of piety. 


\section{https://doi.org/10.1017/9781108691512.008 Published online by Cambridge University Press}

